\title{
Zola's Nana and Kasdaglis's Eleni: Two Female Portraits of the Naturalistic Persona
}

\begin{abstract}
Nikos Kasdaglis is one of the pioneers in the shift of post-war modern Greek prose towards a more realistic and naturalistic form of writing. Kasdaglis, according to literary criticism, revives and redefines "objective" prose by exploiting the doctrines of the naturalist school at the level of both narrative choices and ideological objectives. Therefore, negative characters, social problems, and bleak conditions are dissected and studied in his works, which make reference in the process to Zola's experimental method. In The Thirst (1970), Kasdaglis studies the sexual extravagance of Eleni, a young nurse who exhibits psychopathological sexual behaviour - following French naturalist patterns that tended to analyse borderline characters - so as to demonstrate the dependence of human nature on sexual instinct and biological origins. Kasdaglis, like Zola in Nana, presents a naturalistic female portrait which is characterized by apathy, cynicism, cravings of the flesh, and lack of emotional love. The composition of the novel models the poetics of naturalism in order to highlight the fact that human nature is predetermined by natural laws and social conventions. Kasdaglis manages to form a contemporary naturalistic portrait which makes direct reference to the French model, and demonstrates the significant impact of the French novel on European and modern Greek prose.
\end{abstract}

Keywords: determinism, Kasdaglis, naturalistic persona, naturalist novel, Zola

\section{Introduction}

What is special about Greek prose after the 1940s is that the events of the war deeply influenced post-war novelists. Greek post-war prose, especially that of the first post-war generation, signals a thematic and morphological shift in modern Greek literature. These writers, deeply influenced by the experiences of the German occupation and the Civil War, desired the renewal of prose writing since they believed it was literature's duty to portray the circumstances that shaped the postwar human in Greece in aesthetic terms (Paganos 2002b). The concepts of plausibility, identity, and community formation at a political and aesthetic level occupied the first post-war generation. In an attempt to transform social experience into literary material and renew their narrative tools, the novelists of this genera- 
tion were to study the realistic and naturalistic prose of both international and national literature. Consequently, their dialectic with literary tradition is based on their intention to capture post-war reality rather than hide from it, as well as the fact that the Darwinian interpretation of life by the naturalists matched the obscurity and the injuries that the Greek writers of this period inherited due to social structure. At the same time, in Europe, an indirect shift towards a literature that echoed the writings of the nineteenth century was observed: the survival of violence, for example, is clearly a legacy of nineteenth-century naturalism, as we can see in the novels of World War I and II (Martino 1969).

Additionally, the characters of the post-war novels often share similar photographic-negative traits with the portraits of Zola and Flaubert, in a way that transcends reality and has an element of grotesque, symbolic darkness and the allegoric depiction of destruction. On the other hand, post-war generation writers renew the dynamics of imagining the real by integrating modern narrative choices of objectivity and introspection about the motives and thoughts of their heroes that enhance the symbolic dimension of morbidity (Paganos 1984; Michaels 1987).

Nikos Kasdaglis, a major Greek novelist of this generation, responding to the fragmented world and brutalization of people within the conditions of war, decided to write about the decline of human dignity and reflect upon the human need for survival at any cost (Kasdaglis 2005). According to researchers, Kasdaglis is considered the author of this generation who was most emphatically influenced by naturalistic themes. Indeed, he had creatively assimilated naturalistic writing, not only through the study of the classic works of European literature but also through preceding Greek prose as well as American writers who had modernized naturalism, such as Hemingway, Faulkner, and Steinbeck (Tsirimokou 1988; Martino 1969). The attempt at literary interpretation of the fragmented present and depiction of the survival of the fittest have deep roots in Western philology and are, after the movement of literary naturalism, not new in European literature, however innovatively a writer handles these thematic motifs. Besides, Greece, on the periphery of Europe, has always received the influence of artistic movements without strictly following them, managing instead to assimilate and integrate them into Greek reality (Galaios 2011; Politis n.d.).

This paper aims to reveal the connection between the organization and the ideological purpose of the literary portrait of the naturalistic persona of Eleni in The Thirst (first published in 1970), a novel by Kasdaglis, and Nana in the eponymous work by Emile Zola (first published in 1880). Zola's Nana is a milestone in European prose which brings together a large part of the naturalists' perspectives and aesthetics. The central heroine, Nana, a young and beautiful prostitute, manages to rise socially in nineteenth-century Paris. However, her cynicism and narcissistic apathy lead her to a conflict with the established social norms and an in- 
evitable death. Her rise and fall, justified by her biological identity and her interactions with her social context, function as an allegorical and symbolic dimension of human nature and social structure (Godeau 2008).

Accordingly, Kasdaglis's The Thirst touches upon similar dilemmas. With mature and innovative writing, he portrays a new kind of objectivity (multifocal narrative), presenting the deterministic path of Eleni, a young and beautiful nurse who is carrying the child of her employer, a middle-aged obstetrician. Eleni is obssessed by a pathological eroticism, similarly to Nana, which she is unable to carry out because of her pregnancy; therefore, she desires a miscarriage. Her cynical indifference to others and her sadistic inclinations gradually lead her to clash with social stereotypes and result in a violent death (Lagonikou 2007).

In both works, the literary modification of Darwinian theory is a means of ideological organization and aesthetic expression in the novel. Although it is true that no literary product is born in a vacuum but rather out of the preceding tradition, it can never be exactly the same as its predecessors since it occurs in a later period of time and in a different social context (Delcroix and Hallyn 2000). Thus, the influence and the dialogue in techniques and thematic motifs between the two cultural systems - the French nineteenth-century literary tradition and Greek post-war fiction - is intense and creative, generating both convergences and deviations (Brunel, Pichois, and Rousseau 2003).

\section{The naturalist worldview and the naturalistic persona: From Zola to Kasdaglis}

Zola undoubtedly renewed naturalism and established it (Mitterand 1986); from the preface of Thérèse Raquin to the declaration of the naturalist movement in Roman expériméntal, Zola is interested in the physiology of people, believing that the writer - just like the positivist scientist - can follow the so-called experimental method (Zola 2006 [1880]). Generally, this method of the naturalists is based on the following stages: observation, reflection, and experiment. Thus, the naturalist writer studies the mechanisms and laws that govern nature and society, altering some of the manifestations of those laws and mechanisms in order to reach conclusions (Tsaliki-Milioni 1984).

Literary naturalism derives from Darwin's theory of biological evolution, which, in turn, is based on the theory of natural selection. However, before Darwin's ideas were applied to literature, they had to be transformed in Roman expériméntal by Zola, who interpreted and transformed Darwinian theory into a literary approach to reality, trying to depict physical and human experiences as 
deterministic processes (Lehan 1995; Ayala 2009). Based on literary Darwinism, Zola's literary portraits (Paganos 2002a; Couleau 1996) are often impulsive on account of the oppression the characters experience at the hands of society. In certain conditions, however, they react in a way that predetermines their fate, as in Nana, where a young woman becomes a prostitute due to social predetermination and her sexual bulimia. The end of the work suggests that the human cannot cope with the animal within himself/herself because illness and death are always lurking and are being photographed by the writer in an extreme and raw manner. Additionally, in this way, it is indirectly suggested that family, peace, and work can create a more humanitarian society (Mitterand 1986).

The characters in Zola can be said to follow two types of Darwinism: (a) natural/biological determinism, such as the gene of psychopathology, for example in Aunt Dide's case, passing down various neuroses and psychoses to future generations, and (b) social determinism, with the characteristics of avarice, uncontrollable ambition, and the triumph of egotism.

In naturalist literary works, issues such as hysteria, sexuality, and the pathology of body and soul are overtly presented and emphatically converted into fictional material for the first time. Zola's research on the power of compulsion and the unconscious is a pre-Freudian study of the mysteries of the human psyche and human behaviour, as Zola is particularly interested in desire as the motive for action and the way in which it affects both genders. It is frequent in naturalist works to observe the sexual instinct urging people to act: the sensual female, for example, generates male lust and the male then becomes violent in order to conquer her. Thus, the writer highlights the issue of competition both between men and women and among men (the latter competing over who will prevail). Unfortunately, this power of instinct usually leads to disaster. The characters come from all social classes, and their appearance often reflects their behaviour and personality, as even beautiful young women like Nana and Eleni end up dead as a result of their misguided choices (Horcajo 2002).

Kasdaglis applies many of the above doctrines to his works and forms his own literary identity, modernizing literary tradition. More than other writers of his generation, he cultivates an extreme realism, often emphasizing elements of horror/ repugnance $=$ moral disgust and impoverishment (Tsirimokou 1988; Kasdagli 2007). In The Thirst he places women in the centre of the novel, gives a new dimension to the concept of objective narration (Lagonikou 2007; Tziovas 1987), and studies female sexuality in naturalistic terms (Paganos 1984). Undoubtedly, The Thirst reminds us of Zola's iconic work, Nana, and is a study of the power of instinct and the inescapable biological laws, which do not discriminate between social classes and genders. 


\section{The depiction of sensuality and sexuality}

Naturalist writers identify vision with knowledge, although they concede that the knowledge acquired through vision is not unbiased or one-dimensional. Privileging vision and its connection to knowledge is an interesting technique and reflects the function of writing and reading (Rignal 1993). Hamon (1998) maintains that the naturalist work consists of a series of narrative choices that the author uses in his attempt to persuade the reader that what is described has a general application. He also states that the organization of descriptive portraits of persons in naturalism follows the same logic as constructing the description of inanimate objects. The aim is to have a naturalist text which forms links between objects and people, deciphering the power of impulses and conflicts between people.

Key features of naturalistic personas can be found in Kasdaglis to a great extent. The protagonist of The Thirst is the pregnant nurse Eleni, whose sexual lust remains insatiable throughout the novel. Her continuous efforts to terminate her pregnancy in order to satisfy her sexual desire form the core of the novel. However, Eleni does not perceive sex as a means to gain money as Nana does, ${ }^{1}$ because Kasdaglis develops the Zola model further and constructs the portrait of a neurotic woman who wants to satisfy her impulses by any means. ${ }^{2}$

Through discourse or gaze, Kasdaglis combines Eleni's self-description and description through hetero-observation, just like in Nana. Both in Zola and Kasdaglis, the plot is structured through authorized persons/introspectors (Stanzel 1999) used by the narrator to reveal both their own personality and the personality of others. Thus, Eleni's character and temperament bear the mark of the male gaze. Her sensuality guides her actions, acquiring, as in the Zola model, a symbolic dimension:

Her feet were well-shaped and long, a bit thick. Blackened by the sun. The tight skirt showed the extended lower part of the thigh. She grabbed my look straight away, and slid the chair, exposing the legs. Laughing. She didn't care to speak slowly. ${ }^{3}$ (Kasdaglis 1990 [1970], 44)

The example of Muffat observing Nana's naked body through the mirror is also illustrative of the heroine's sexual power (as is also the case with Kasdaglis's Eleni, who dominates the male characters with sensuality):

1 However, Nana also has lovers and mistresses for her own satisfaction, regardless of their money, such as Zorz or the young prostitute she pays to be with her.

2 On the interest of the naturalists in the study of divergent mental states, see Lagarde and Michard (1969).

3 Translations are my own unless otherwise noted. 
Muffat, [...] la voyait dans la glace, avec ses épaules rondes et sa gorge noyée d'une ombre rose. Et il ne pouvait, malgré son effort, se détourner de ce visage que l'œil fermé rendait si provocant [...] comme pâmé de désirs. (Zola 1984 [1880], 152)

Thus, in both novels, the beauty and the provocative behaviour of Eleni and Nana respectively monopolizes the interest and the gaze of other characters, predetermining all future actions (Dezalay 1984). The following excerpt, for example, shows through her lover/employer's own narration not only Eleni's cruelty, but also the strong attraction she exerts over him:

She cut me off laughing, without caring [...]. I may be older, and not fit, but I didn’t only want her baby. (Kasdaglis 1990 [1970], 48-49)

At the same time, Kasdaglis is innovative in the sense that he intensifies the dynamics of the indirect presentation of his heroes and heroines by presenting various characters recounting and describing the same events from their point of view but always having Eleni at the centre of attention.

The naturalists were particularly interested in psychopathological conditions; their aim was revealing - in biological terms - how body and soul, society, and the individual interact with each other. Thus, the two women are presented as violent and impulsive, as is indicated by their actions and behaviour towards others and by their vulgar discourse. In both novels, upper and lower social classes share the same violent erotic instincts which lurk in the human psyche and can, if appropriate conditions occur, be released. Both rich and poor, outcasts and educated bourgeois, behave in a similar way because human nature is characterized by selfishness. More specifically, Eleni, like Nana, is characterized by an intense sexuality that goes as far as perversion and eradicates every moral barrier. Sex is the primary drive, while motherhood is disavowed by both female characters (Arnoux-Farnoux et al. 2008). Eleni constantly complains about her inability to make love because she cannot stand male odour during her pregnancy, a fact that indicates her desensitization. In the following extract, she experiences an intolerable situation because her pregnancy-oriented sexual aversion contradicts her idiosyncrasy, just like in Nana:

Other [women] do not bear even a little water. Only I cannot stand a man near me, I feel like throwing up. Like a knocked-up bitch! - If I wasn't hot, I wouldn't care. But to be so horny and unable to stand a man close to you. (Kasdaglis 1990 [1970], 222) 
The deliberately exaggerated sexuality of the two women and their lack of moral inhibitions are depicted in the guise of their sexy outfits. Their behaviour reveals that the basis of any erotic relationship, according to the naturalist model, is the carnal need which conceals aggression and possessiveness - consider, for instance, the relationship of Fontan and Nana. Violence begins due to the fear of dominance of the other, and it is a pattern of the struggle for survival, combined with the need to possess the lover/mistress as an object of personal satisfaction. This fear is studied both by Kasdaglis and Zola. For example, in the following extract, through Muffat's gaze, we see the sensual but brutal Nana as the object of his desire. The demonization of Nana's sexuality becomes a symbolic and allegorical extension of the social failure to accept, control, and civilize human instincts. Nana's biological superiority and eroticism, like Eleni's, are a natural punishment of the social elite:

Nana était toute velue, [...] tandis que, dans sa croupe et ses cuisses de cavale, dans les renflements charnus creusés de plis profonds, qui donnaient au sexe le voile troublant de leur ombre, il y avait de la bête. C'était la bête d'or, inconsciente comme une force, et dont l'odeur seule gâtait le monde. (Zola 1984 [1880], 218)

Likewise, in The Thirst neither Eleni's pregnancy, nor the wound on her face, nor even her bleeding decrease her libido and charm. Sexual scenes are presented with naturalist clarity, which reveals her carnality and sadistic domination, as is clear in the scene where she sexually harasses Teresa. The following excerpts are indicative of Eleni's sexual perversions as well as Nana's, since both writers aim to induce repugnance in the reader:

I didn't even know how to act, though I liked it. And she liked it, too, I'd felt her nipple. I stood behind her and lowered her dress, stroking her arms. Unbuttoned her bra, and she was left naked from the bottom up. She leaned with effort to take off her tights, she might have been embarrassed. As I was behind her, I hugged her, clenched her breasts, and held her tight. Her body grew tense with disgust. (Kasdaglis 1990 [1970], 90)

Both Eleni and Nana exhibit homosexual tendencies as an indication of their sexual bulimia:

(a) Eleni: "It was impossible. She smelled lightly, and I liked her smell. I embraced her waist, and got laughs - I hadn't touched a woman before. I groped her and found the rubber of her panty - of course all women wear panties. In the bedroom I tried to strip her and she was surprised.” (Kasdaglis 1990 [1970], 42-43)

(b) Nana: “À vingt reprises, tragique dans ses fureurs de femme trompée, Nana courut à la poursuite de cette gueuse, qui s'envolait par toquade, ennuyée du bien-être de l'hôtel. [...] Un jour même, elle rêva de duel; il y en avait une de trop.” (Zola 1984 [1880], 323) 
Eleni's violent psychopathological behaviour is also revealed when she attempts to perform an abortion on herself ${ }^{4}$ and on the unsuspecting Teresa as well. Moreover, there are scenes of women being physically harmed, for instance during Eleni's quarrel with the prostitute (Kasdaglis 1990 [1970], 121, 125-126), which reminds us of Nana being beaten by Fontan while begging him not to leave her.

The naturalistic escalation of sexual drives is also clearly expressed through the constant association of humans with animals. Eleni uses the simile of a "knocked-up bitch" to describe her aversion to sexual intercourse due to her pregnancy and the simile of a "turned-on mare" to express her intense sexual desire, and Kostas compares her to a "cat in sexual heat” (Kasdaglis 1990 [1970], 99). Similarly, the hypersexual and beautiful Nana looks like a deer with her glossy mane, her glistening skin, awaking the carnal instincts of men in order to trap them, ${ }^{5}$ while the narrator describes her as an "aroused cat." These associations, common to the naturalists, are designed to emphasize the power and primacy of instincts, as humans cannot defeat their own nature.

\section{Biological superiority and naturalistic symbolism in the organization of the two literary portraits}

The narrative axis of the naturalist worldview both in Kasdaglis's and Zola's novels is structured around contrasts of youth vs maturity, health vs disease, and attractiveness vs repellence, which revolve around Eleni's and Nana's lust. The female characters manipulate opponents and helpers (Greimas 1959, 2005) to defuse their sexual thirst. In both novels, the narrative focuses on the robustness and the biological superiority of the two women, characteristics which justify the Darwinian attraction they exert on others. In this way, the beautiful and husky Eleni contrasts with the weak and sickly Teresa, who - despite her efforts - cannot keep her child and also fails to sustain the interest of her husband, who craves

\footnotetext{
4 The abortion scene occurs when Eleni has forced the midwife to help her and ends up completing the action herself. In the midwife's words: "She forced me, I thought she would choke me. I did whatever I could. I made her wash first, and then, while I was bent over her, I watched her thighs and her calves flail about suddenly, from pain. And she didn't make a sound. She had stuffed a towel in her mouth and bit it. And then, when the pain wore off, and I was trying to stop the blood, again she showed great courage" (Kasdaglis 1990 [1970], 132-133).

5 "faisant voir sa nuque où des cheveux roux mettaient comme une toison de bête" (Zola 1984 [1880], 26).
} 
Eleni. In Zola's novel, Nana contrasts with her sickly son who is dying and with the aging prostitutes, who - being unable to gain the interest of wealthy lovers become jealous of her.

In both novels, the biologically strong defeats or dominates others, while female fertility and beauty - related to age - become instruments of domination. In both novels, Darwinism is organized around the contrast of attractiveness/fertility vs aging/marginalization. More specifically, Eleni's beauty promises fertility, while the deformity of Teresa due to illness, or the deformity of the doctor's wife due to aging, is equivalent to sterility.

Eleni's final fall, as well as Nana's, occurs due to a reversal of the natural order. It is a clinical imbalance: Nana and Eleni do not want their pregnancies as they believe they will deprive them of their pleasures. Thus, although the natural order is attractiveness $\rightarrow$ sex $\rightarrow$ pregnancy, in the case of Eleni - due to neurosis we have the opposite: pregnancy $\rightarrow$ miscarriage $\rightarrow$ sex. In Nana we also observe the heroine's dislike for the foetus she carries:

\footnotetext{
Elle éprouva un tel ennui, qu'elle fit tout au monde pour dissimuler sa grossesse. Ses peurs nerveuses, ses humeurs noires venaient un peu de cette aventure, dont elle gardait le secret, avec une honte de fille-mère forcée de cacher son état. Cela lui semblait un accident ridicule, quelque chose qui la diminuait et dont on l'aurait plaisantée. Hein; La mauvaise blague! Pas de veine, vraiment! Il fallait qu'elle fût pincée, quand elle croyait que c'était fini. Et elle avait une continuelle surprise, comme dérangée dans son sexe; ça faisait donc des enfants, même lorsqu'on ne voulait plus et qu'on employait ça à d'autres affaires? La nature l'exaspérait, cette maternité grave qui se levait dans son plaisir, cette vie donnée au milieu de toutes les morts qu'elle semait autour d'elle. Est-ce qu'on n'aurait pas dû disposer de soi à sa fantaisie, sans tant d'histoires? (Zola 1984 [1880], 381-382)
}

Within the context of naturalism, therefore, the two women are led to a dead end. Eleni's death after falling from the stairs during a quarrel with an old man who harassed her and Nana's death by a sudden unknown disease are two different ways in which the deterministic worldview is applied to the novels. Ultimately, the way Kasdaglis depicts the portrait of Eleni in The Thirst, his commitment to the study of female sexuality, and the ill-fated ending reveal the naturalist ideology that permeates his work, just like that of Zola (Seymour-Smith 1979; Matz 2004; Becker 1963). ${ }^{6}$

6 Love in Zola is not so much a desire for fertility, for his heroines have problematic relationships, but rather the engine which moves the world forwards. Their sexuality satisfies men, but at the same time traps and enslaves them (Mitterand 1986, 74-75). 


\section{Conclusions}

Undoubtedly, The Thirst is one of the most important naturalistic novels of Greek post-war fiction. It enters into a dialogue with Zola's Nana regarding the characters' violent instincts and cynicism. The Thirst constitutes an example of the dialogue between Greek post-war prose and the naturalist worldview. The pessimistic appraisal of human nature, the deterministic imposition of biological and social forces, the insensitivity and apathy of society, the falling characters, the carnality of love, and the simplicity of motivation are all found in The Thirst with similar ideological objectives as in Nana. The heroines of the novels become a means for the writers to display the impact of the conflict between the individual and social structure. The depiction of female sexuality functions, additionally, as a means of criticizing the hypocrisy and immorality of contemporary society through depictions of the raw and the detestable (Paganos 1984).

Both heroines share common characteristics in their presentation, and the organization of their literary portraits serves similar ideological purposes in spite of their differences. More specifically, the nurse Eleni, despite her good social status, is a misfit, and this is reflected in her language and morals, just as is the case with the prostitute Nana, who tries in vain to transcend her class. At the same time, the two women become the object of the desire of the male characters, who become addicted to their animalistic beauty and sensuality. Thus, through the reactions of the rich and educated males, both writers reveal that bourgeois society is not so different from the world of crime, despite the prejudices that divide them. Consequently, the depictions of the two women's attitudes and sexual delusions include an element of sadistic cruelty and the need to punish their lovers, while the dominance of instinct serves as a justification for their fall.

The two women share the same "thirst," the same moral disintegration, since their impulsive-animalistic nature is hidden under their prudishness and the conventions of society. Their discourse and behaviour manifest a "biologicalized" sense of superiority but also reveals a distinct psychopathology which pushes them towards more and more extreme situations, leading them to a dead end. Their neurotic nature combined with physical strength causes temporary dominance among other females and brings economic and social gains as well, while motherhood is an obstacle to their sexual satisfaction. Indeed, in The Thirst, Eleni's self-inflicted attempt at miscarriage becomes the central theme of the novel and forms a contrast of sex vs pregnancy, which challenges the natural order and foreshadows the fall of the heroine. Their individual cases evolve gradually into a study of the biologically and socially ill, an attempt to investigate the limits of the healthy and psychopathological. Thus, their sexual obsessions and demonic cruelty become allegorical dimensions of the dead end of human 
destiny and become a kind of expressionistic depiction of eternally unbalanced gender relations.

In conclusion, the two anti-heroic subjects of Kasdaglis and Zola move with apathy towards their final moral-spiritual and physical doom, since naturalism requires representative characters that reflect harsh and negative human nature, and they gradually lose the illusion of free choice (Paganos 1984). At the same time, both writers offer an indirect criticism of the society of their time, which is unable to tame humans, but also unable to accept sexual desire as a basic element of human nature.

\section{Works cited}

Arnoux-Farnoux, Lucile, Isabelle Gadoin, Chris Rauseo, and Catherine Lanone. Destinées féminines (naturalisme européen: Nana, Tess, Effi Briest). Neuilly: Atlande, 2008.

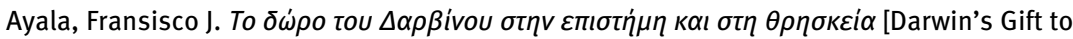

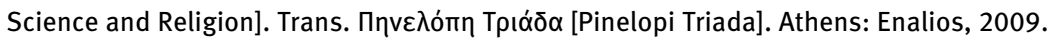

Becker, George J. Documents of Modern Literary Realism. Princeton: Princeton University Press, 1963.

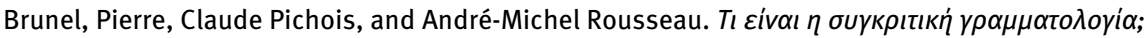

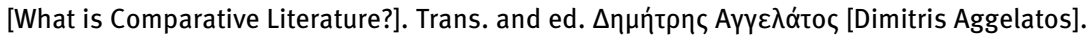
4th ed. Athens: Patakis, 2003.

Couleau, Cristèle. Premières leçons sur illusions perdues, un roman d'apprentissage. Paris: Presses Universitaires de France, 1996.

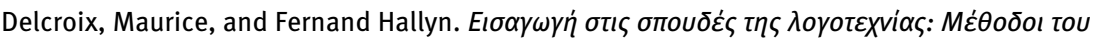

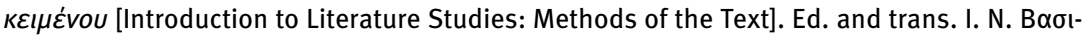
$\lambda \alpha \rho \alpha ́ \kappa \eta \varsigma$ [I. N. Vasilarakis]. Athens: Gutenberg, 2000.

Dezalay, Auguste. “Commentaires et notes d’Auguste Dezalay.” Nana. By Émile Zola. Paris: Librairie General Française, 1984. 471-509.

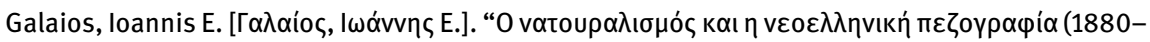

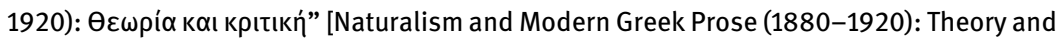
Criticism]. Doctoral thesis. National and Kapodistrian University of Athens, 2011.

Godeau, Florence. Destinées féminines à l'ombre du Naturalisme, Nana (E. Zola), Tess d'Urberville (T. Hardy), Effi Briest (T. Fontane). Paris: Desjonqueres, 2008.

Greimas, Algirdas J. "Les Problèmes de la description mécanographique." Cahiers de lexicologie 1.2 (1959): 47-75.

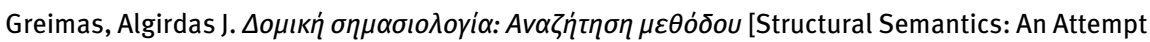

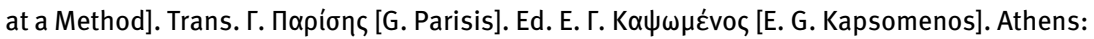
Patakis, 2005.

Hamon, Philippe. Le Personnel du roman: Le Système des personnages dans les Rougon-Macquart d'Émile Zola. Geneva: Librairie Droz, 1998.

Horcajo, Carlos. Le Naturalisme: Un mouvement littéraire et culturel du XIXe siècle. Paris: Magnard, 2002.

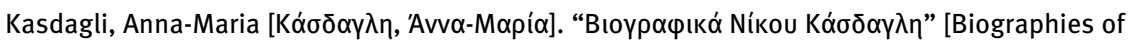

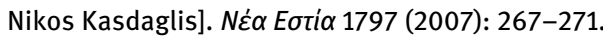




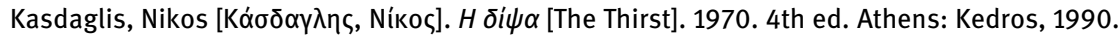

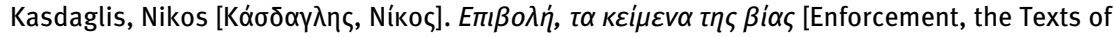
Violence]. Athens: Sokolis, 2005.

Lagarde, André, and Laurent Michard. XIXe siècle : Les Grands Auteurs français du programme. Paris: Bordas, 1969.

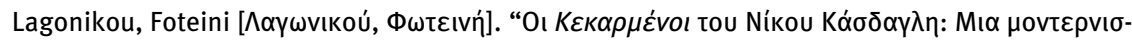

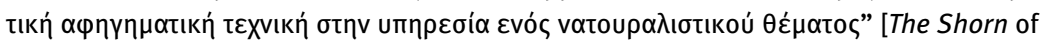
Nikos Kasdaglis: A Modernist Narrative Technique in the Service of a Naturalist Theme].

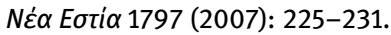

Lehan, Richard. "The European Background." The Cambridge Companion to American Realism and Naturalism. Ed. D. Pizer. Cambridge: Cambridge University Press, 1995. 47-74.

Martino, Pierre. Le Naturalisme français (1870-1895). Paris: Librairie Armand Colin, 1969. Matz, Jesse. The Modern Novel: A Short Introduction. Oxford: Blackwell, 2004.

Michaels, Walter Benn. The Gold Standard and the Logic of Naturalism: American Literature at the Turn of the Century. Vol. 2. Berkeley and Los Angeles: University of California Press, 1987.

Mitterand, Henri. Zola et le naturalisme. Paris: P.U.F, 1986.

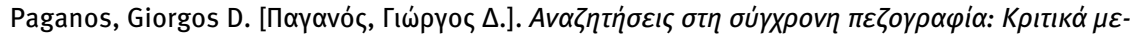
$\lambda \varepsilon \tau \eta \dot{\mu} \mu \tau \alpha$ [Quests in Contemporary Literature: Literary Studies]. Athens: Kastaniotis, 1984.

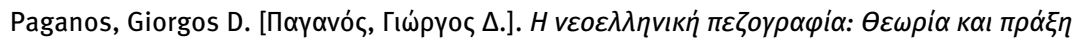
[Modern Greek Prose: Theory and Practice]. Vol. A. Thessaloniki: Kodikas, 2002a.

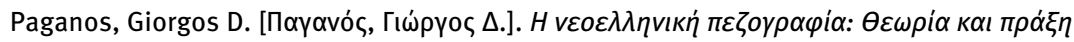
[Modern Greek Prose: Theory and Practice]. Vol. B. Thessaloniki: Kodikas, $2002 \mathrm{~b}$.

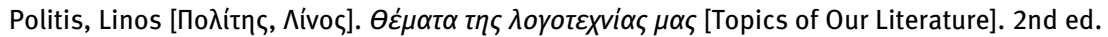
Thessaloniki: Konstantinidis, n.d.

Rignall, John. Realist Fiction and the Strolling Spectator. London and New York: Routledge, 1993.

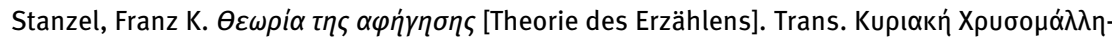
Henrich [Kyriaki Chrysomalli-Henrich]. Thessaloniki: University Studio Press, 1999.

Seymour-Smith, Martin. An Introduction to Fifty European Novels. London and Sydney: Pan, 1979.

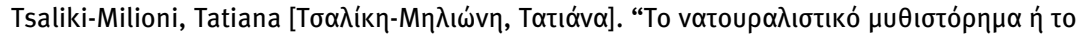

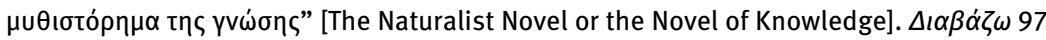
(1984): 21-25.

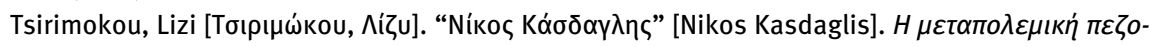

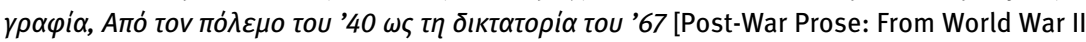
to the Dictatorship of '67]. Vol. C. Athens: Sokolis, 1988. 305-377.

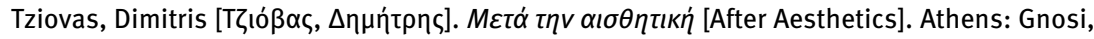
1987.

Zola, Émile. Nana. 1880. Paris: Librairie General Française, 1984.

Zola, Émile. Le Roman expérimental. 1880. Paris: Flammarion, 2006. 
Tasos Michailidis holds a PhD in Modern Greek Literature and is a postdoctoral researcher at the Faculty of Philosophy of the National and Kapodistrian University of Athens, Greece. He regularly participates in conferences and has published several papers. His research interests focus on nineteenth- and twentieth-century modern Greek literature, literary theory, comparative literature, and creative writing. 
